\title{
PLANNING FOR INDONESIAN HERITAGE CITY
}

\author{
Dwi Hariyawan S. \\ Direktur Pemanfaatan Ruang, Kementerian Agraria dan Tata Ruang Jl. Raden Patah I No. 1, \\ Kebayoran Baru, Jakarta, Indonesia \\ Email: dhariyawan@yahoo.com
}

\begin{abstract}
Conservation of cultural heritage is one of the issues in spatial planning in Indonesia. Besides being a mandate from the Spatial Planning Law, conserving cultural heritage is an effort to realize a livable and sustainable city. This article presents how planning policies can play a role in conserving cultural heritage as an important value of an area.
\end{abstract}

Keywords: conservation, heritage city, spatial planning

\section{Introduction: Past and Present of Heritage City In Indonesia}

The $21^{\text {st }}$ century is an urban century. In this age, number of cities is increasing and the urban population is rapidly increasing. In 2007, there was an important event in the history of human civilization, where for the first time there was a demographic shift in which the urban population was greater than the number of rural population. Thus in Indonesia, the number of people living in urban areas is greater than in rural areas.

Historically, urban life in Indonesia has always been marked by the presence of technology and culture that is considered new in the development of the city. For example, cities built between $17^{\text {th }}$ and $18^{\text {th }}$ centuries were influenced by maritime trade, while cities in the $19^{\text {th }}$ and $20^{\text {th }}$ centuries were influenced by the industrial revolution. The history leaves a trail of historic cities with assets in the form of historic buildings and other historic assets. The rise of urban development that is currently oriented towards economic growth unfortunately poses a threat to the survival of heritage assets in Indonesia. Some old cities can harmoniously grow along with new cities. However, lot of old cities were abandoned and their historical buildings were ignored (Martokusumo, 2014). In this context, we can't forget a speech delivered by Prof. Eko Budihardjo, an architectue and urban planning figure, "... a city without ancient buildings is like a person without memory".

Although development is guided by systematic planning, the gap between conservation and development often occurs. In the context of recent rapid urban development, all nations in the world have agreed on the importance of sustainable urban development where conservation is an important agenda. One important issue is to conserve the city's identity and heritage assets in the context of urban development through spatial planning. This article will show various efforts made by the Ministry of Agrarian Affairs and Spatial Planning / National Land Agency in realizing the conservation goals of the heritage city. 
INTERNATIONAL PROCEEDINGS

LOCAL GENIUSES GENERATE FUTURE DESIGN, 16-17 November 2018

\section{Framework of Management and Conservation of Heritage City}

Indonesian heritage is natural heritage, cultural heritage, and saujana (cultural landscape) heritage which is a unity between natural and cultural heritage (Charter of Indonesian Heritage Conservation 2003). The management and conservation of the heritage city is an effort to integrate heritage conservation efforts in the urban environment with city planning in Indonesia.

This is in line with the recent global city's development policy in voicing the importance of conserving the city's heritage assets. The $11^{\text {th }}$ Sustainable Development Goals (SDGs), adopted in Presidential Regulation No. 59 of 2017, also known as urban goal, which aims to make urban areas inclusive, safe, strong, and sustainable include "... promoting and maintaining the world's cultural heritage and world natural heritage".. This explicitly emphasizes that economic development together with social and environment accompanied by cultural aspects will ensure sustainable results.

The management of the heritage city is placed in line with the spirit of the Sustainable Development Goals and the New Urban Agenda (NUA). Basically, cities are not just economic machines, but also a storage of the potential of culture and heritage. The potential can take the form of art, customs, language, site, architecture, and historical areas with heritage value. However, both development and conservation should be balanced and go hand in hand.

This effort will need a legal back up. The reality is that although heritage conservation efforts in Indonesia have an adequate legal basis, but they are spread in several laws and regulations. There are at least four laws, namely Law 28/2002 on Building, Law 27/2007 on Spatial Planning, Law 32/2009 on Environmental Protection and Management and Law 11/2010 on Cultural Heritage.

The framework for management and conservation of the heritage city in Indonesia does not explicitly exist. However, based on these regulations, the framework of heritage city is the need to protect and maintain part of the city in with cultural heritage, including areas and / or buildings that have heritage values for the city. The objective of heritage conservation in the spatial planning is to accommodate the need to protect cultural heritage at its variety of forms.

Tabel 1: Regulation of Preservation of Heritage Cities in Indonesia

\begin{tabular}{ll}
\hline \multicolumn{1}{c}{ Regulations } & \multicolumn{1}{c}{ Content } \\
\hline Law 28/2002 on Buildings & $\begin{array}{l}\text { The need for protection of buildings that have history and the } \\
\text { mandatory requirements to accommodate and consider local socio- } \\
\text { cultural values in the development and maintenance of architectural } \\
\text { buildings and historic buildings. }\end{array}$ \\
\hline $\begin{array}{ll}\text { Law 26/2007 on Spatial } \\
\text { Planning }\end{array}$ & $\begin{array}{l}\text { Designation of cultural heritage areas and strategic areas from the } \\
\text { perspective of socio-cultural interests, at the national / provincial and } \\
\text { regency / city level. }\end{array}$ \\
\hline Law 32/2009 on & $\begin{array}{l}\text { Determination of policies on environmental management and spatial } \\
\text { planning must pay attention to religious values, traditions and other } \\
\text { anvironmental Protection } \\
\text { values that exist in society. }\end{array}$ \\
\hline Law 11/2010 on Cultural & $\begin{array}{l}\text { Protection and preservation of cultural heritage must be carried out } \\
\text { optimally through protection of heritage values. }\end{array}$ \\
\hline Source: Taufan Magement &
\end{tabular}

Source: Taufan Madiasworo, 2015 
We can also refer to the international policy on heritage conservation. In UNESCO's Recommendations Concerning the Safeguarding and Contemporary Role of Historic Areas (1976), it is mentioned that conservation of heritage cities is defined as measures for the protection, preservation and restoration of cities by paying a special attention to developments and adaptations of cultural heritage into contemporary life. This approach is reinforced by the 1987 Washington Charter that emphasizes the need to integrate heritage conservation and development of the city.

In the last few years, various recommendations and conservation charter has been reformulated to make heritage conservation be more relevant to the current urban issue. The result is the Recommendation on the Historic Urban Landscape adopted by UNESCO in 2011. The recommendation mentions that spatial planning has an important role to combine heritage conservation and socioeconomic development in harmony.

\section{Tabel 2: International Regulations Governing the Conservation of Heritage Cities}

\begin{tabular}{|c|c|}
\hline Regulations & Content \\
\hline $\begin{array}{l}\text { Recommendation } \\
\text { concerning the } \\
\text { Preservation of Cultural } \\
\text { Property (1968) }\end{array}$ & $\begin{array}{l}\text { The government should be able to issue binding regulations and an } \\
\text { adequate budget so that rescue of heritage can be carried out, } \\
\text { including introducing high tax treatment for any activity that has the } \\
\text { potential to damage the heritage, requiring the establishment of an } \\
\text { institution that is responsible for saving heritage and providing } \\
\text { guidance to the community. }\end{array}$ \\
\hline $\begin{array}{l}\text { Recommendation of } \\
\text { Nairobi concerning the } \\
\text { Safeguarding and } \\
\text { Contemporary Role of } \\
\text { Historic Areas (1976) }\end{array}$ & $\begin{array}{l}\text { The government should conduct a detailed survey of architectural, } \\
\text { socio-economic, and cultural value in the heritage area and its } \\
\text { surroundings, prepare a conservation plans for every heritage objects } \\
\text { that need to be integrated in an integrated manner and inventory of } \\
\text { available public funds that can be used for conservation efforts. This } \\
\text { conservation effort must go hand in hand with the socio-economic } \\
\text { development of the local community }\end{array}$ \\
\hline $\begin{array}{l}\text { Washington Charter on } \\
\text { the Conservation of } \\
\text { Historic Towns and Urban } \\
\text { Areas (1987) }\end{array}$ & $\begin{array}{l}\text { The conservation plan should be able to answer directly the problems } \\
\text { of history and architecture conservation and the harmonious } \\
\text { relationship between heritage area and the city. The new activities } \\
\text { must be in harmony with the character of the heritage city. }\end{array}$ \\
\hline $\begin{array}{l}\text { Recommendation on } \\
\text { Historic Urban Landscape } \\
\text { (2011) }\end{array}$ & $\begin{array}{l}\text { The planning process of heritage city should incorporate heritage } \\
\text { conservation and socio-economic development harmoniously. } \\
\text { Contemporary architecture must be able to improve the values of } \\
\text { heritage city. Socio-economic development must be the long-term goal } \\
\text { of heritage conservation. }\end{array}$ \\
\hline
\end{tabular}

From the various statutory texts mentioned above, a heritage city has heritage assets with national or local significant and must have a management system to conserve its significance. An important issue is integrating the conservation of heritage cities with spatial planning as part of its management plan. Spatial planning should be able to accommodate the diversity of heritage assets with historical and cultural values that form the specific character of the city. In addition, conservation activities are dynamic and should also aim to create a safe, comfortable, productive and sustainable urban space. 


\section{Efforts to Realize Pusaka City}

In late 1960s, cities in Indonesia has started to give an attention to the conservation and management of heritage assets as part of their planning and development policy. It was in 1970s that the government of Jakarta has declared some areas, including Jakarta Kota (Old City), Menteng and Kebayoran Baru, as conservation areas. These areas were later included in the Jakarta's Master Plan 1985-2005 (Eryudhawan, 2017). However, Jakarta is just one of the very few cities who consider the benefit of conserving urban heritage or the old city center to the city (Eryudhawan, 2017).

In the 1980s, heritage movements by community to conserve heritage assets began to emerge. Various communities and conservation organizations were formed in Indonesian cities and later they formed a network called the Indonesian Heritage Conservation Network (JPPI). The network aims to raise the awareness about the importance of Indonesia's heritage conservation. One important moment related to the development of the heritage movement in Indonesia was the declaration of 2003 Indonesian Heritage Conservation Charter. Later on, conservation of heritage cities has become a collaborative work between government, local government and community with support of private sector (Wijayanto, 2016).

In 2008 in Surakarta, Joko Widodo, the former Mayor of Surakarta held a "World Heritage Cities Conference and Expo for the Europe-Asia region" which was attended by 37 countries. During this event, he initiated the establishment of the Indonesian Heritage City Network (JKPI) with other eight mayors, including Ternate, Pekalongan, Pangkal Pinang, Pontianak, Yogyakarta, Medan, Ambon, Denpasar, Surabaya, Palembang, Blitar, and Surakarta. According to Jero Wacik, the former Minister of Culture and Tourism, "... if the construction of a mall displaces historical buildings, that is not true because it will eliminate the national identity. If maintaining heritage buildings then ignoring the development of cities, it is also not true because we have to create jobs for the welfare of the people. "

Following the development of heritage movement, the government of Indonesia, particularly the Ministry of Land Issue and Spatial Planning through the agency of spatial planning, has made efforts to realize the Indonesia heritage city through various innovative programs as follows.

1) Heritage City Management and Conservation Program (P3KP)

In 2012, Directorate General of Spatial Planning, formerly part of the Ministry of Public Works, takes the initiative in fostering the conservation of the heritage city by establishing Heritage Management and Conservation Program (Program Penataan dan Pelestarian Kota Pusaka or P3KP). The program was to facilitate the improvement the capacity of local government to manage their heritage assets. This activity is at the same time to identify and study the character of heritage cities in Indonesia with a diversity of cultural heritage assets.

The program relates to efforts to implement sustainable urban development. For DJPR, this program is an effort to support the implementation of the Spatial Planning Law especially in the strategic socio-cultural areas. 
$\mathrm{P} 3 \mathrm{KP}$ is a strategic effort with the city socio-spatial entity approach to help the improvement of spatial planning with adequate heritage management. During this program, cities is facilitated to identify their heritage assets and accommodated in the planning as Heritage City Action Plan (RAKP). One strategy in managing this program is utilizing RAKP to create a partnership and collaboration with other ministries or agencies.

2) Thematic City Program

The term "thematic city" starts from the mandate of the President of the Republic of Indonesia, for local government to plan and their city with its own theme (thematic). Thematic city can be defined as:

- Cities that are built based on their potential and uniqueness so that they have a clear identity as reflected in their spatial utilization;

- The city built by elements in the use of space (facilities, infrastructure and spatial patterns), so that it has a clear image that is easily recognizable and becomes its attraction; and

- Cities that show a link between the city's identity and the activities of its inhabitants.

In determining the city theme, what is needed is a specific theme according to the character that is owned and rooted in the community. In other words, each city in Indonesia must be able to identify its character, which is elaborated in its city vision and development mission.

The city themes that currently exist such as Banjarmasin as the City of Thousand Rivers. The city of Banjarmasin with the theme of the Thousand Rivers is seen as a city developed based on river life.

3) Support for Spatial Planning Policy for the Conservation of Cultural Heritage in Indonesia Efforts of the Ministry of Agrarian and Spatial Planning to conserve the area or city with socio- cultural value in Indonesia explicitly stated in the legal basis of spatial planning, starting with the regulation concerning the National Spatial Planning (RTRWN) until the regulation on the guidelines for the formulation of Spatial Plans at the Provincial to District / City Level as follows:

- PP 26 of 2008 and PP 13 of 2017 concerning the National Spatial Planning (RTRWN): Establishing a National Strategic Area, including the National Strategic Area with the Social and Cultural Interest.

- Permen ATR / Head of BPN No. 1 of 2018 concerning the Guidelines for the Preparation of Provincial, Regency and City Spatial Planning which mandates the Determination of Provincial, District and City Strategic Areas with Strategic Area with the Social and Cultural Interest.

- Permen ATR / Head of BPN No. 16 of 2018 concerning Guidelines for Preparation of Spatial Detail Plans which mandate the designation of SubBWP area priority. 


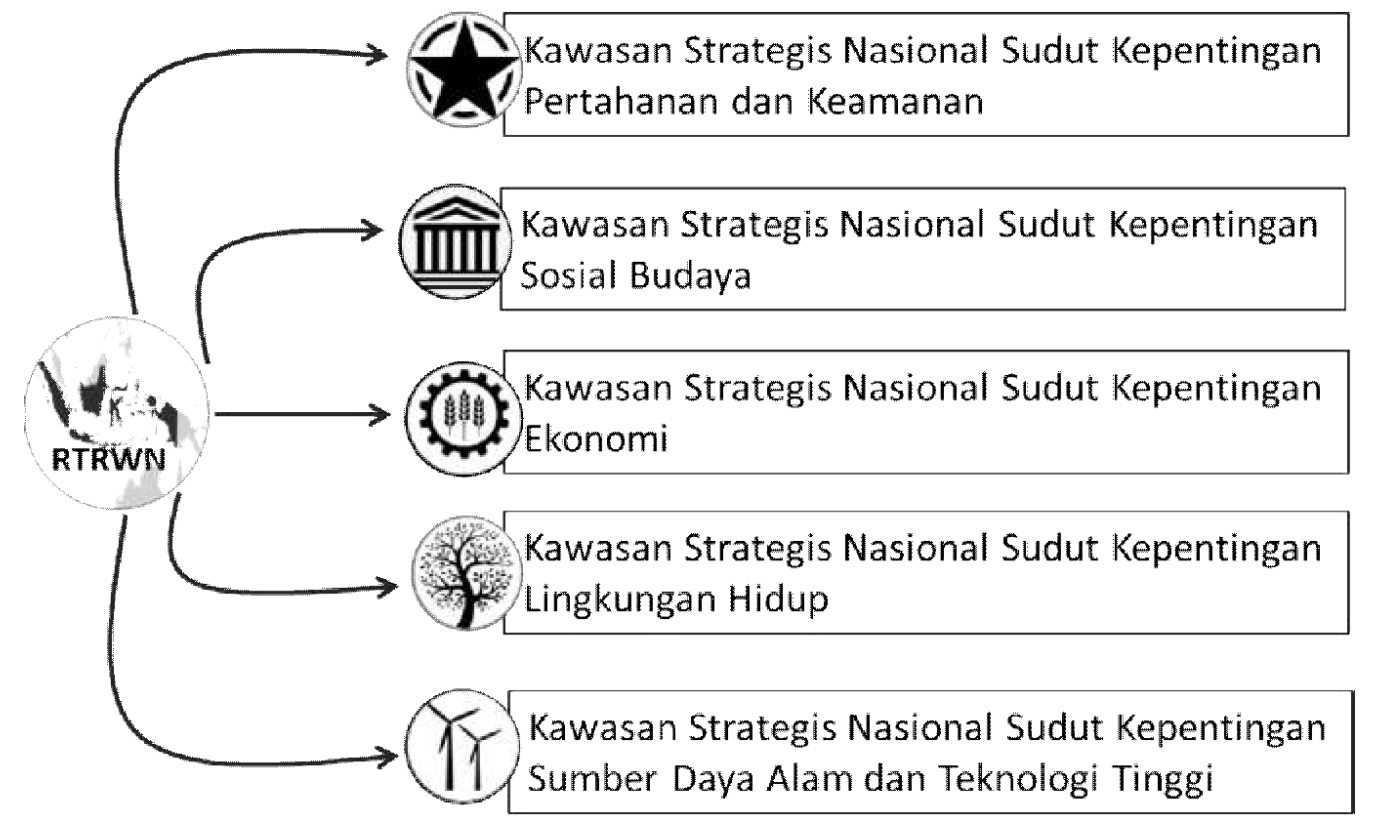

Figure 2: Designation of National Strategic Areas in the National Spatial Planning (RTRWN) Source: Directorate General of Spatial Planning, Ministry of ATR / BPN

4) Thematic City Space Utilization Program

Different character from thematic city needs enthusiasm from the local government to maintain and develop their the theme. Thematic cities is understood to be able to give opportunity to the development of people welfare both economically and socially. Some cities has successfully shown their experience to be well known due to their city themes. The various efforts carried out, should not only be at the achievement of the city vision but how the theme can be used as inspiration for development. The program of space utilization and development program referred to in this guideline is a realization in realizing the theme of a city.

In 2018, the directorate of utilization has border area development activities. In addition to realizing the quality of space in the border region, what is referred to as the real border region also has a theme that refers to historical values, as well as other values that need to be understood. Through the program in this border city, the border area is expected to have a strong identity, while at the same time providing benefits for the development of the city.

\section{Conclusion}

The urban age gives actually challenges the city to grow with its own strength. In this case, the city is expected to have the capacity to recognize its potential as a primary source for its development.

Urban knowledge as the result from the long process of urban development is a valuable source for the city. Spatial planning, in addition to being a guide in 
bridging the past and the future, is also a medium for the city to recognize its potential, including its history. Through spatial plans that have been prepared at various levels of regulation, it is expected that a variety of values, including historical and cultural values can be maintained and passed to the next generation.

\section{Reference}

Madiasworo, Taufan (2015). "Melestarikan Kota Pusaka Kita". Buletin Cipta Karya No. 06/ XIII/Juni 2015, available at http://ciptakarya.pu.go.id/dok/bulletin/buletinCK_jun15.pdf (accessed 23 October 2018).

Eryudhawan, Bambang (2017). "Urban Conservation in Jakarta since 1968", in SPAFA Journal Vol. 1 No. 1/2017. Available at https://www.researchgate.net/publication/321136365_Urban_Conservation _in_Jakarta_since_1 968 (accessed 31 October 2018).

Martokusumo, Widjaja (2014). “Kota (Pusaka) sebagai Living Museum”. Diskusi Temu Pusaka Indonesia 2014. Available at https://www.researchgate.net/publication/268981328_KOTA_PUSAKA_S EBAGAI_LIVING_MUSE UM (accessed 31 October 2018).

Roesmanto, Totok. Memoar Prof Eko, Available at http://www.konteks.org/memoar-prof-eko (accessed 23 October 2018).

Wijayanto, Punto (2016). "Building the Notion of Heritage City in Indonesia: The Role of Local Group Communities". Workshop Proceedings on the Heritage of Ancient and Urban Sites: Giving Voice to Local Priorites), Available at https://www.iseas.edu.sg/images/centres/nalanda_sriwijaya_centre/compil ations/heritage_wor

kshop/1_punto_wijayanto_heritage_city_indonesia.pdf (accessed 23 October 2018).

---. Undang-Undang No. 26 Tahun 2007 tentang Penataan Ruang. Available at https://www.atrbpn.go.id/Publikasi/Peraturan-Perundangan/UndangUndang/undang-undang- nomor-26-tahun-2007-1849 (accessed 31 October 2018).

---. Peraturan Pemerintah No. 26 Tahun 2008 tentang RTRWN. Available at https://www.atrbpn.go.id/Publikasi/Peraturan-Perundangan/PeraturanPemerintah/peraturan- pemerintah-nomor-26-tahun-2008-1138 (accessed 31 October 2018).

---. Peraturan Pemerintah No. 13 Tahun 2017 tentang Perubahan PP Nomor 26 $\begin{array}{llll}\text { Tahun } 2008 \text { tentang } \text { RTRWN. Available at } & \end{array}$ http://sitarunas.atrbpn.go.id/index.asp?m=RTRWN\&n=DokumenRTRWN- Revisi\&no=PP\%20No.\%2013\%20Tahun\%202017 (accessed 31 October 2018).

---. "Mayday 23: World Population Becomes More Urban Than Rural”. Available at https://www.sciencedaily.com/releases/2007/05/070525000642.htm (accessed 31 October 2018).

---. "Menbudpar Resmikan Jaringan Kota Pusaka Indonesia", Available at https://news.detik.com/berita/1025968/menbudpar-resmikan-jaringan-kotapusaka-indonesia (accessed 23 October 2018). 
INTERNATIONAL PROCEEDINGS

LOCAL GENIUSES GENERATE FUTURE DESIGN, 16-17 November 2018

---. "Jokowi Minta Kepala Daerah Bangun Kota Tematik". Available at https://bisnis.tempo.co/read/666020/jokowi-minta-kepala-daerah-bangunkota-tematik (accessed 23 October 2018).

---. "Recommendation on the Historic Urban Landscape". Available at https://whc.unesco.org/uploads/activities/documents/activity-638-98.pdf (accessed 23 October 2018). 